\title{
FARMERS' PREFERENCES AND PERCEPTION INFLUENCING DECISION TO GROW BIO-FORTIFIED PROVITAMIN A CASSAVA
}

\author{
NNEKA M. CHIDIEBERE-MARK AND GODS'POWER C. ANYANWU \\ Department of Agricultural Economics, Extension and Rural Development, Imo State University \\ Owerri, Nigeria \\ Corresponding email: nnekamark@gmail.com
}

\begin{abstract}
The study analysed farmers' preferences and perception influencing decision to grow biofortified provitamin A cassava. Specifically, the study described the socio-economic characteristics of cassava farmers in the study area; identified sources of information on biofortified provitamin A cassava; ascertained farmers' perception of the key attributes of biofortified provitamin A cassava; ascertained farmers' preference for biofortified provitamin A cassava; analysed sio-economic determinants of willingness to grow bio-fortified provitamin A cassava, and, constraints that hinder farmers' decision to grow bio-fortified provitamin A cassava. It was hypothesized that the socio-economic characteristics of farmers significantly influence the decision to grow bio-fortified provitamin A cassava. Structured questionnaire and interview schedule were used to elicit data from 90 cassava farmers in the study area. Data collected were analysed using descriptive and inferential statistics. The result revealed that farmers in the study area were mostly female, married, with a mean age of 50 years, mean years of formal education of 12 years, farming experience of 6 years and a mean household size of 6 persons. The sources of information on bio-fortified provitamin A cassava include agricultural extension agents, farmer groups and radio. The result also showed that farmers perceived bio-fortified provitamin A cassava to be able to make yellow Garri (Cassava granules); have low sugar content. The farmers preferred bio-fortified provitamin A cassava because of its low sugar content, ability to make yellow cassava granules (Garri) which makes it attractive for selling, and contain vitamin A which is necessary to reduce blindness. Poor access to information, poor access to bio-fortified provitamin A cassava stem, and high moisture content were some of the major constraints that affect the decision to grow bio-fortified provitamin A cassava by farmers' in the study area. The study recommends that farmers should be given easy access to bio-fortified provitamin A cassava stems and extension agents should make more visits to cassava farmers to enlighten them on the benefits of growing biofortified provitamin A cassava.
\end{abstract}

Keywords: Cassava, Biofortified, provitamin A, Farmers, Imo State

https://doi.org/10.4314/jafs.v18i1.12

Journal of the Faculty of Agriculture and Veterinary Medicine, Imo State University Owerri website: www ajol.info/index.php/jafs

Open Access article distributed under the terms of the Creative Commons License CC BY-NC 


\subsection{INTRODUCTION}

Cassava (Manihot esculenta Crantz) is one of the important food crops grown in the tropics (Phillips et al., 2004). It is the fourth most important staple in the world after rice, wheat and maize. Africa is the largest producer of cassava in the world accounting for over $54 \%$ of the total production, and Nigeria takes the global lead as the largest producer of cassava in the world with annual output of about 50 million metric tonnes from a cultivated area of about 3.7 million ha (FAO, 2020). Cassava is the main staple crop in Nigeria and an important food security crop (McNulty \& Oparinde, 2015). An estimated 40\% of Africans rely on the crop as a significant source of calorie (Nweke, 2004). In Nigeria, cassava products are consumed in various forms. Cassava roots are used traditionally to produce foods like garri, edible starch, fufu, tapioca, and cassava flour. Garri which is the most consumed among the different forms of cassava products is a granular flour made from cassava roots by peeling, washing, grating, fermenting, pressing and roasting (De Moura et al., 2015). Garri is perceived by processors to be an interesting product, because it is a convenience food with good storability and, on average, with better market demand than other cassava products. It can compete with rice in convenience and price in urban and rural markets (Sanni, et al., 2009).

While the commonly available local white cassava varieties can provide most of the body's daily energy requirements, it does not provide sufficient proteins, essential micronutrients and vitamin A required for a healthy and productive life. Micronutrients (Iron, Zinc and Vitamin A) have wide-ranging functions in the body, and, as such, inadequate intakes can have many negative biological effects such as poor growth, cognitive impairments and ultimately increased risk of morbidity and mortality, depending on which micronutrients in particular are lacking (Lockyer, et al., 2018). Smallholder farming families and other vulnerable groups in low- and middle-income countries are at high risk of micronutrient deficiency, or "hidden hunger," with outcomes that include stunting, anemia, blindness, even premature death-especially for women and children (HarvestPlus, accessed 1/8/2020). Hidden hunger also weakens immune systems. HarvestPlus (accessed 2020) reports that over two billion people around the world suffer from 'hidden hunger' or micronutrient deficiencies, and the symptoms of micronutrient deficiencies cannot be seen - such as lower IQ, lower resistencae to diseases, and fatigue. This is why this form of malnutrition is termed as hidden hunger. Vitamin A deficiency (VAD) is a serious public health problem globally. Poor diet is one of the primary causes hidden hunger in Nigeria (UNICEF, 2019), and it is reported that about $30 \%$ of children under five and almost $20 \%$ of pregnant women are vitamin A deficient (Maziya-Dixon et al., 2006; Ayinde, 2016).

In recent years, National Root Crops Research Institute (NRCRI), Umudike in collaboration with International Institute of Tropical Research Institute (IITA), Ibadan was involved in the development of highly nutritious root and tuber crops including Cassava through a process known as biofortification, in other to complement Nigerian Government's efforts to check Vitamin A deficiency. The rationale for cassava bio-fortification is hinged on the fact that cassava is a staple food in Nigeria especially among the poor who have limited access to a variety of food products. Biofortification is the process of breeding nutrients into food crops, Journal of the Faculty of Agriculture and Veterinary Medicine, Imo State University Owerri website: www ajol.info/index.php/jafs

Open Access article distributed under the terms of the Creative Commons License CC BY-NC 
either by using natural breeding techniques or by using genetically modified organisms. Biofortification changes the colour of Cassava roots from white to deep yellow, due to the increase in pro-vitamin A content. Although biofortified staple crops contain only small amounts of micronutrients, frequent consumption in large quantities throughout the year will provide a steady supply of micronutrients. Bio-fortified provitamin A Cassava which is a new variety of Cassava, is reported to provide up to $40 \%$ of the daily recommended Vitamin A intake for children less than 5 years old (De Moura et al., 2015).

In spite of the benefits of biofortied foods and its availability in Nigeria, especially cassava, the adoption rate is still low. Njoku et al., (2014) opines that the adoption rate of elite cultivars by farmers is about $40 \%$ and this negates the aim for breeding such improved cultivars. Farmers are not a homogeneous group and their preferences and priorities are highly heterogeneous. Farmers' perception and preference for particular attributes influences their actions in terms of choosing one crop or variety over another. Perception and knowledge guide decision making and consequently farmers' action (Kisauzi et al., 2012). The decision to grow bio-fortified provitamin A cassava is likely to be influenced by the preference for its traits/attributes. Farmers have various production objectives, but upmost among them is the need to provide sufficient food for the farm family. Some identified cassava attributes preferred by farmers as documented in literature includes, but are not limited to; high yielding with many big roots, early maturing, durable (stay well underground, for at least two years), tolerate poor soils, are cattle resistant, low moisture content, drought-resistant (in the North), more starchy (some like less).

The availability of a huge domestic cassava market for an increasing urban and rural population, as well as the export of high-quality cassava products represents potential entry points for farmers to grow provitamin A-rich yellow cassava. The availability has potentials to reduce Vitamin A deficiencies if accepted and consumed by the target population, especially the poor and middle-income populations. However, little is known about farmers preferences and perception of this biofortified variety of cassava compared to the commonly available white varieties. It is on this premix that the study was designed to understand farmers' perception and preferences influencing decision to grow bio-fortified provitamin A cassava in other to inform policy. The specific objectives were to; describe the socioeconomic characteristics of cassava farmers; identify sources of information on bio-fortified provitamin A cassava; ascertain farmers' perception of the key attributes of bio-fortified provitamin A cassava; ascertain farmers' preference for biofortified provitamin A cassava; analyse determinants of willingness to grow bio-fortified provitamin A cassava, and, constraints that hinder farmers' decision to grow bio-fortified provitamin A cassava. It was hypothesized that the socio-economic characteristics of farmers significantly influence the decision to grow bio-fortified provitamin A cassava.

\section{MATERIALS AND METHODS}

The study was carried out in Owerri Agricultural Zone, Imo State. Owerri Agricultural Zone is located at the southwestern part of Imo State, Southeast, Nigeria. It is bounded on the Journal of the Faculty of Agriculture and Veterinary Medicine, Imo State University Owerri website: www ajol.info/index.php/jafs

Open Access article distributed under the terms of the Creative Commons License CC BY-NC 
East by Abia State, on the west by Anambra and Rivers States, on the North by Isu and Isiala Mbano Local Government Area of the State and on the south by Abia and Rivers State (IADP, 2000). Owerri Agricultural zone is made up of eleven Local Government Areas. The zone is richly endowed with fertile land suitable for the growth of cassava, vegetable, maize, and other crops. There are two main seasons in the zone-dry and rainy seasons. The mean annual temperature is between $26-28^{\circ} \mathrm{C}$ with a relative humidity of about 98\% during the wet seasons (IADP, 1990). A multi-stage sampling technique was used in selecting respondents for the study. The sample consist of 90 cassava farmers. Primary data were obtained, using a structured questionnaire administered to cassava farming households including farmers who growers and non-growers of bio-fortified pro-vitamin-A cassava varieties). Cassava farmers were selected from the lists obtained from the Agricultural Development Programme (ADP) office in the zone and contact farmers in the selected communities.

Descriptive and inferential statistical tools like frequency, percentages; mean score and binary probit regression model were used in analysing data for the study. A dichotomous dependent variable was constructed to indicate the decision of the farmers to grow biofortified provitamin A cassava.

The binary probit regression model is specified as:

$$
\boldsymbol{f}^{\prime}\left(\boldsymbol{\mu}_{\boldsymbol{Y}}\right)=\Phi^{\mathbf{1}}(\boldsymbol{P})_{=\operatorname{Pr}\left(\mathrm{y}=1 / \mathrm{x}_{\mathrm{i}}\right)=\Phi(\mathrm{x} \beta)}
$$

Where:

$\mathrm{P}_{\mathrm{r}}=$ is the probability that a farmer grows bio-fortified provitamin A Cassava with a given set of characteristics, $X_{i}$ (Grow bio-fortified provitamin A Cassava=1, Not grow=0)

$\beta_{i}=$ is the vector of coefficients of the vector of covariates or coefficients, $X_{i}$

$\mathrm{X}_{\mathrm{i}}=$ Independent variables

The independent variables were,

$\mathrm{X}_{1}=\operatorname{Sex}($ male $=1$, female $=0)$

$\mathrm{X}_{2}=$ Education (number of years spent on formal education).

$\mathrm{X}_{3}=$ Household size (number of persons)

$\mathrm{X}_{4}=$ Farming experience (years)

$\mathrm{X}_{5}=$ Extension visit (number of times visited in a year)

$\mathrm{X}_{6}=$ Marital status (married $=1,0=$ otherwise)

$\mathrm{X}_{7}=$ Farm size (hectare)

ei $=$ error term.

Estimated coefficients do not quantify the influence of the explanatory variables on the value of the dependent variable. Hence, the marginal effect is used for interpretation. The marginal effect of the dependent variables is the effect of a unit change of this variable on the probability $\mathrm{P}(\mathrm{Y}=1 / \mathrm{X}=\mathrm{x})$, given that all other explanatory variables are constant:

$$
\frac{\partial P\left(y_{i}=1 \mid x_{i}\right)}{\partial x_{i}}=\frac{\partial E\left(y_{i} \mid x_{i}\right)}{\partial x_{i}}=\varphi\left(x_{i}^{\prime} \beta\right) \beta
$$

Journal of the Faculty of Agriculture and Veterinary Medicine, Imo State University Owerri website: www ajol.info/index.php/jafs

Open Access article distributed under the terms of the Creative Commons License CC BY-NC 


\subsection{RESULTS AND DISCUSSION}

\subsection{Socio-economic characteristics of cassava farmers}

The socio-economic characteristics of cassava farmers in the study area were presented in Table 1 and discussed according to their sex, age, marital status, years spent in school, farming experience, house hold size, extension visit, farm size, and occupation. The result in Table 1 shows that $52.2 \%$ and $47.8 \%$ of the cassava farmers in Owerri agricultural zone were females and males respectively. This implies that cassava production is not gender exclusive but is mostly carried out by females. This is in line with the findings of Kalu et al, (2016). The mean age of cassava farmers in the study area was 49 years. This shows that majority of the farmers were in their active age. The result showed that majority (95.6\%) of the respondents were married. The mean number of years spent in school was 10 years. This implies that on average the farmers had a minimum of secondary education and that the farmers were educated enough to appreciate the benefit of bio-fortified provitamin A cassava which could influence their decision to grow. Education increases the level of awareness of farmers on available technologies, in this case, bio-fortified provitamin A cassava and its benefit to health. Farmers with low level of education or without education would be less receptive to improved farming techniques (Okoye et al., 2004; Ajibefun \& Aderinol, 2004).

The mean years of farming experience 5.7years and indicates that the farmers were experienced and knowledgeable on cassava production as a staple crop. Experience in cassava farming also exposes the farmers to different attributes of cassava varieties, which may inform their decisions on the varieties to cultivate. This may affect their perception and preference for bio-fortified provitamin A cassava. The mean household size of the farmers was 6 persons. This shows that the farmershad a relatively large households, which is important in cassava farming as they assist as family labour, thereby reducing the cost of production. The mean number of extensions visits during the planting period was 3 times. The mean farm size was 4 hectares. This result implies that cassava farmers in the study area had small farm holdings.

The result of the major occupation of the cassava farmers further shows that the farmers were engaged in different occupation, in addition to farming. About $45.56 \%$ were civil traders, while $25 \%$ and $16.7 \%$ were traders and farmers respectively. However, on further questioning, it was revealed that though the respondents had a diversity of other occupations, they all still engaged in farming. Some had farms while some reported they had home gardens. This implies that the rural households do not depend solely on one occupation for their livelihood.

\subsection{Sources of information on bio-fortified provitamin A cassava}

The result of the farmers sources of information on bio-fortified provitamin A cassava is presented in Table 2. It shows that the farmers obtained information from agricultural Extension Agents (65.56\%), farmer groups (61.11\%), radio (5.56\%) and leaflet/newspaper $(1.11 \%)$. This implies that the farmers had more access to information on bio-fortified provitamin A cassava from extension agents and farmer groups. There is need for a sustained Journal of the Faculty of Agriculture and Veterinary Medicine, Imo State University Owerri website: www ajol.info/index.php/jafs

Open Access article distributed under the terms of the Creative Commons License CC BY-NC 
effort of the research institutes through the field extension agents to continually update and educate the farmers of the benefits og growing improved varieities, especially biofortified provitamin A cassava. This information could be disseminated also through farmer groups and opinion leaders. Omoregbee and Banmeke (2014) opines that cassava farmers apparently rely more on fellow farmers and family friends for information about farming than formal information sources such as extension worker, radio, television and newspapers.

\subsection{Perception of key attributes of bio-fortified provitamin A cassava}

Table 3 shows farmers' perception of key attributes of bio-fortified provitamin A cassava. The farmers perceived that bio-fortified provitamin A cassava is good to make yellow Garri (Mean $=2.74)$, contains provitamin A (Mean $=2.60)$, and it is high yielding (Mean $=2.40)$. Others include; early maturity (Mean 2.38), resistant to disease (Mean $=2.27$ ), and easy to peel (Mean $=2.47$ ). The result also reveals that farmers perceived bio-fortified provitamin $\mathrm{A}$ cassava to dewater fast after grating and fermenting (mean 1.833). Standard deviation ranged from 0.63-0.87. This implies that the farmers differed in their opinion about the attributes of bio-fortified provitamin A cassava. The positive attributes are expected to influence the farmers decision to grow biofortified provitamn A cassava. The understanding of the farmer as to the benefits of provitamin $\mathrm{A}$ in the diet to prevent hidden hunger amongst the farm family, especially for growing up children and pregnant mothers would likely result in a positive outcome, which is the farmers decision to grow biofortified provitamin A cassava.

\subsection{Farmers preference for bio-fortified provitamin A cassava}

The preference of cassava farmers for bio-fortified provitamin A cassava is represented on Table 4. The result reveals that farmers prefer bio-fortified provitamin A cassava to the traditional white cassava because it has low sugar content ( $90 \%$; ranked $1^{\text {st }}$ ), it makes yellow Garri $\left(87.7 \%\right.$, ranked $\left.2^{\text {nd }}\right)$, contains pro vitamin a (ranked $\left.3^{\text {rd }}\right)$ and early maturity $(83.3 \%$; ranked $\left.4^{\text {th }}\right)$. Yellow coloured Garri is more preferable than white coured Garri because it is more attractive and commands a higher market. The yellow colour is usually achieved by the addition of palm oil (Elaeis guineensis) during fermentation or roasting. The biofortified provitamin A cassava naturally has the yellow colour, and hence saves the farmer the cost of using additives (palm oil). Also, the low sugar content of yellow garri is a healthier choice especially amongst the elderly, and hence may likely influence the decision to grow the variety.

\subsection{Socio-economic determinants of farmers' willingness to grow bio-fortified provitamin A cassava}

The result of the binary probit regression of the determinants of farmers willingness to grow bio-fortified provitamin A cassava is presented in Table 5. From the result of the marginal effect, the coefficient for sex and extension visits were statistically significant at p0.05 and 0.1 respectively.

The coefficient for sex is -0.2250056 with a probit of 0.051 and was negative. The result indicates that being male decreases the probability of the farmers' willingness to grow bio-

Journal of the Faculty of Agriculture and Veterinary Medicine, Imo State University Owerri website: www ajol.info/index.php/jafs

Open Access article distributed under the terms of the Creative Commons License CC BY-NC 
fortified provitamin A cassava. This implies that female farmers were more willing to grow bio-fortified provitamin A cassava than males. This may be an indication that more females grow cassava than males and also utilize it at home for different purpose like garri and fufu.

The coefficient of extension visit is 0.1989886 with a P-value of 0.096 and was positive. The result shows that the probability of increased extension visit increases the probability of farmers willingness to grow bio-fortified provitamin A cassava. Extension visit/contact increases the chances of farmers accepting innovations and technologies, as farmers who get more extension visit are more knowledgeable on current technologies than their counterparts.

Therefore, the hypothesis that the socio-economic characteristics of farmers affected farmers decision to grow bio-fortified provitamin A cassava was rejected for sex and extension visit.

\subsection{Constraints to Decision to Grow Bio-fortified Provitamin A Cassava}

The result of the constraints influencing the cassava farmers' decision to grow bio-fortified provitamin A cassava is presented in Table 6. The result shows that some of the constraints reported were; poor access to information about bio-fortified provitamin A cassava (Mean score $=2.69$ ) and high moisture content of bio-fortified provitamin A cassava (Mean score = 2.4). Dewatering is one of the salient processes in making Garri, as the moisture content determines when it is ready for roasting and the storability of the finished product. High moisture content negatively would influence the farmers decision to grow bio-fortified provitamin A cassava. The standard deviation ranged from $0.747-0.593$ implying that the farmers differed in their opinion about the constraints to bio-fortified provitamin A cassava.

Smale et al. (2001) argue that farmers choose crop varieties based on a set of attributes that best respond to production constraints, assures consumption preferences and satisfies specific market requirements. The result is consistent with the findings of Onyeneke et al. (2019) who opines that high moisture content results in non-adoption of biofortified provitamin A cassava.

\section{CONCLUSION AND RECOMMENDATION}

It can be concluded that bio-fortified provitamin A cassava has good attributes with immense benefits. Farmers perception of the attributes and traits of the biofortified provitamin A cassava influence their decision to grow. Extension agents have an active role to play in educating farmers on the benefits of growing biofortified provitamin A cassava. It is recommended that extension agent should pay more visits to farmers more to enlighten them on the importance of bio-fortified provitamin A cassava as a staple. Also, more cassava stem/cuttings should be made easily accessible by the research institutes through the various Agricultural development offices in the States. 


\section{REFERENCES}

Ajibefun, I.A., \& Aderinola, E.A. (2004). Determinants of technical efficiency and policy implication in traditional agricultural production: empirical study of Nigerian food crop farmers. Final Report Presentation at Bi-annual Research Workshop of African Economic Research Consortium, Nairobi, Kenya.

Ayinde, O. E. (2016). Risk analysis in innovation system: a case study of production of Vitamin A cassava variety among farmers in Nigeria. Addis Ababa, Ethiopia: $5^{\text {th }}$ International Conference of the African Association of Agricultural Economists.

De Moura, F. F., Moursi, M., Lubowa, A., Ha, B., Boy, E., Oguntona, B., Sanusi, R. A., \& Maziya-Dixon, B. (2015). Cassava Intake and Vitamin A Status among Women and Preschool Children in Akwa-Ibom, Nigeria. PloS one, 10(6), e0129436. https://doi.org/10.1371/journal.pone.0129436

FAO (2020). Nigeria at a glance. Food and Agriculture Organization of the United Nations. http://www.fao.org/nigeria/fao-in-nigeria/nigeria-at-a-glance/en/

HarvestPlus (2020). Nutrition. www.HarvestPlus.org accessed 1/8/2020

IADP (1990). Annual report 2000. Imo Agricultural Development Programme (IADP), Imo State, Nigeria.

IADP (2000). Annual report 2000. Imo Agricultural Development Programme (IADP), Imo State, Nigeria.

Kalu, C.A., Nto, P.O., \& Okoye, B.C (2016). Empirical analysis of socio-economic characteristics and profitability status of cassava entrepreneurs' in Abia State. National Root Crops Research Institute Umudike.

Kisauzi, T., Mangheni, M. N., Sseguya, H. and Bashaasha, B. (2012). Gender dimensions of farmers' perceptions and knowledge on climate change in Teso Sub - Region, Eastern Uganda. African Crop Science Journal, 20(2): 275 - 286.

Lockyer, S., White, A., \& Buttriss, J.L. (2018). Biofortified crops for tackling micronutrient deficiencies - what impact are these having in developing countries and could they be of relevance within Europe? Nutrition Bulletin, 43, 319-357. https://doi.org/10.1111/nbu.12347

Maziya-Dixon, B.B., Akinyele, I.O., Sanusi, R.A., Oguntona, T.E., Nokoe, S.K., \& Harris, E.W. (2006). Vitamin A Deficiency Is Prevalent in Children Less Than 5 years of Age in Nigeria. The Journal of Nutrition, 136(8):2255-2261. https://doi.org/10.1093/jn/136.8.2255

McNulty, E. \& Oparinde, A. (2015). Cassava Value Chain in Nigeria: A Review of the Literature to Inform the Integration of Vitamin A Cassava. HarvestPlus Research for Action, NO. 4, August, 2015. 
Njoku, D.N., Egesi, C. N., Gracen, V. E., Offei, S. K., Asante, I. K., \& E. Y. Danquah (2014). Identification of pro-vitamin a cassava (Manihot esculenta Crantz) varieties for adaptation and adoption through participatory research. Journal of Crop Improvement, 28(3), 361-376. https://doi.org/10.1080/15427528.2014.888694

Nweke, F. I. (2004). New challenges in the cassava transformation in Nigeria and Ghana. Discussion Paper No. 118, Environment and Production Technology Division, International Food Policy Research Institute, Washington, DC, USA.

Okoye, B. C., Okorji, E. C., \& Asumugha, G. N. (2004). Outlook on production economics of paddy rice under resource constraints in Ebonyi State. Proceedings of the 38th Annual Conference of the Agricultural Society of Nigeria. (ASN) held $17^{\text {th }}-21^{\text {st }}$ October 2004, Lafia Nasarawa State.

Omoregbee, F.E. \& Banmeke, T.O.A. (2014). Information needs of cassava farmers in Delta State of Nigeria. Tanzania Journal of Agricultural Sciences, 12 (2): 20-25.

Onyeneke, R.U., Emenekwe, C.C., Munonye, J.O., Olaolu, M.O., Izuogu, C.U., IbrahimOlesin, S., Amadi, M.U., Njoku, C.L., \& Obi, J.N. (2020). Adoption of Bio-fortified Pro-Vitamin-A Cassava and Health Outcome of Farming Households in Abia and Anambra States Nigeria. Journal of Agricultural Extension, 24(2): https://dx.doi.org/10.4314/jae.v24i2.9

Phillips, T. P., Taylor, D.S., Sanni, L, \& Akoroda, M.L. (2004). A Cassava Industrial Revolution in Nigeria: The Potential for a New Industrial Crop. Rome, Italy: Food and Agriculture Organization of the United Nations and International Fund for Agricultural Development.

Sanni, L.O., Onadipe, O.O., Ilona, P., Mussagy, M.D., Abass, A., and Dixon, A.G.O. (2009). Successes and challenges of cassava enterprises in West Africa: a case study of Nigeria, Bénin, and Sierra Leone. IITA, Ibadan, Nigeria. 19 pp.

Smale, M., Bellon, M. and Gomez, J. A. A. (2001). Maize diversity, variety attributes and farmers' choices in South-eastern Guanajuato, Mexico. Economic development and cultural change, 50 (1): 201-225.

UNICEF (2019). The State of the World's Children 2019. Children, Food and Nutrition: Growing well in a changing world. UNICEF, New York. 
Journal of Agriculture and Food Sciences

Nneka M. Chidiebere-Mark \& Gods'power C.

Volume 18, Number 1, April, 2020 pp $130-142$

Anyanwu

APPENDICES

Table 1 Distribution of Cassava farmers by socio-economic characteristics

\begin{tabular}{|c|c|c|}
\hline Socio-economic variable & Frequency & Percent \\
\hline \multicolumn{3}{|l|}{ Sex } \\
\hline Female & 47 & 52.20 \\
\hline Male & 43 & 47.80 \\
\hline \multicolumn{3}{|l|}{ Age } \\
\hline $31-40$ & 8 & 8.9 \\
\hline $41-50$ & 47 & 52.20 \\
\hline $51-60$ & 30 & 33.3 \\
\hline $61-70$ & 5 & 5.60 \\
\hline Mean & 50 years & \\
\hline \multicolumn{3}{|c|}{ Number of years spent in formal education } \\
\hline 0 & 1 & 1.10 \\
\hline $1-6$ & 5 & 5.60 \\
\hline $7-12$ & 61 & 67.80 \\
\hline $13-18$ & 23 & 25.50 \\
\hline Mean & 12.5 years & \\
\hline $1-5$ & 56 & 62.22 \\
\hline $6-10$ & 25 & 27.78 \\
\hline $11-15$ & 5 & 5.56 \\
\hline $16-20$ & 4 & 4.44 \\
\hline Mean & 5.7 years & \\
\hline \multicolumn{3}{|c|}{ Cultivated bio-fortified provitamin A Cassava } \\
\hline Yes & 50 & 55.60 \\
\hline No & 40 & 44.40 \\
\hline \multicolumn{3}{|l|}{ Major occupation* } \\
\hline Farming & 18 & 20.00 \\
\hline Artisan & 10 & 11.10 \\
\hline Civil servant & 37 & 41.11 \\
\hline Trade & 41 & 45.56 \\
\hline
\end{tabular}

Source: Own computation from field survey data, 2019

$\mathrm{n}=90 ; *=$ Multiple responses recorded 
Journal of Agriculture and Food Sciences

Nneka M. Chidiebere-Mark \& Gods'power C.

Volume 18, Number 1, April, 2020 pp 130 - 142

Table 2 Sources of information on biofortified provitamin A Cassava*

Anyanwu

\begin{tabular}{lll}
\hline Source & Frequency* & Percentage \\
\hline Radio & 5 & 5.56 \\
Leaflet/banner & 1 & 1.11 \\
Farmer group & 55 & 61.11 \\
Extension agents & 59 & 65.56
\end{tabular}

Source: Own computation from field survey data, 2019

$*$ = Multiple responses recorded

Table 3 Farmers' perception of key attributes of bio-fortified provitamin A Cassava

\begin{tabular}{|c|c|c|c|c|c|c|c|c|c|}
\hline \multirow[t]{2}{*}{ Attributes } & \multicolumn{2}{|c|}{ Agree } & \multicolumn{2}{|c|}{ Disagree } & \multicolumn{2}{|c|}{ Undecided } & \multirow[t]{2}{*}{ Total } & \multirow{2}{*}{$\begin{array}{l}\text { Mean } \\
\text { Score }\end{array}$} & \multirow[t]{2}{*}{ SD } \\
\hline & $\mathbf{F}$ & Score & $\mathbf{F}$ & $\begin{array}{c}\text { Scor } \\
\text { e }\end{array}$ & $\mathbf{F}$ & Score & & & \\
\hline $\begin{array}{lr}\text { Makes yellow } & \text { Garri } \\
(\text { Cassava granules) } & \end{array}$ & 77 & 231 & 3 & 6 & 10 & 10 & 247 & $2.744^{*}$ & 0.65 \\
\hline Contains pro vitamin $\mathrm{A}$ & 66 & 198 & 12 & 24 & 12 & 12 & 234 & $2.600 *$ & 0.72 \\
\hline High yielding & 52 & 156 & 22 & 44 & 16 & 16 & 216 & $2.400 *$ & 0.78 \\
\hline High dry matter & 12 & 36 & 48 & 96 & 30 & 30 & 162 & 1.800 & 0.66 \\
\hline Early maturity & 51 & 153 & 23 & 46 & 16 & 16 & 215 & $2.388^{*}$ & 0.78 \\
\hline $\begin{array}{l}\text { Dewaters fast after grating } \\
\text { and fermenting }\end{array}$ & 13 & 39 & 49 & 98 & 28 & 28 & 165 & 1.833 & 0.66 \\
\hline Resistant to disease & 49 & 147 & 17 & 34 & 24 & 24 & 205 & $2.277 *$ & 0.87 \\
\hline Easy to peel & 62 & 186 & 9 & 18 & 19 & 19 & 223 & $2.477 *$ & 0.83 \\
\hline $\begin{array}{l}\text { Many products can be made } \\
\text { from it }\end{array}$ & 63 & 189 & 15 & 30 & 12 & 12 & 231 & $2.566^{*}$ & 0.72 \\
\hline $\begin{array}{l}\text { Its consumption helps to } \\
\text { prevent blindness }\end{array}$ & 62 & 186 & 13 & 26 & 15 & 15 & 227 & $2.522 *$ & 0.77 \\
\hline
\end{tabular}

Source: Own computation from field survey data, 2019

* Mean above discriminating index

Discriminating index $=2.0$

Journal of the Faculty of Agriculture and Veterinary Medicine, Imo State University Owerri website: www ajol.info/index.php/jafs

Open Access article distributed under the terms of the Creative Commons License CC BY-NC 
Table 4 Farmers Preference for Bio-fortified Provitamin A Cassava

\begin{tabular}{|c|c|c|c|}
\hline Attributes & Frequency & Percentage & Rank \\
\hline Low sugar content & 81 & 90 & $1^{\text {st }}$ \\
\hline Makes yellow granules (Garri) & 79 & 87.7 & $2^{\text {nd }}$ \\
\hline Contains pro vitamin A & 78 & 86.6 & $3^{\text {rd }}$ \\
\hline Early maturity & 75 & 83.3 & $4^{\text {th }}$ \\
\hline $\begin{array}{l}\text { Consumption of bio-fortified Provitamin A } \\
\text { Cassava products can improve health condition }\end{array}$ & 73 & 81.1 & $5^{\text {th }}$ \\
\hline $\begin{array}{l}\text { Consumption of bio-fortified Provitamin A } \\
\text { Cassava product can help prevent blindness in } \\
\text { children and disease infection in reproductive } \\
\text { women }\end{array}$ & 73 & 81 & $5^{\text {th }}$ \\
\hline Easy to peel & 70 & 77.7 & $7^{\text {th }}$ \\
\hline $\begin{array}{l}\text { Many products can be made from bio-fortified } \\
\text { Provitamin A Cassava compared to white } \\
\text { Cassava }\end{array}$ & 70 & 77.7 & $7^{\text {th }}$ \\
\hline High yielding & 67 & 74.4 & $9^{\text {th }}$ \\
\hline Resistant to disease & 60 & 66.6 & $10^{\text {th }}$ \\
\hline High dry mater & 50 & 55.5 & $11^{\text {th }}$ \\
\hline Dewaters fast after grating and fermenting & 38 & 42.2 & $12^{\text {th }}$ \\
\hline
\end{tabular}

Source: Own computation from field survey data, 2019 
Table 5 Marginal effect

\begin{tabular}{lllll}
\hline Variable & $\mathbf{d y} / \mathbf{d x}$ & Std. Err & $\mathbf{Z}$ & $\mathbf{P}(\mathbf{Z})$ \\
\hline Sex & $-.2250056^{*}$ & .1153 & -1.95 & 0.051 \\
Education & .022923 & .02514 & 0.91 & 0.362 \\
Household size & -.0106934 & .0407 & -0.26 & 0.793 \\
Farm experience & -.0040052 & .00664 & -0.60 & 0.546 \\
Extension visit & $.1989886^{* *}$ & .1195 & 1.67 & 0.096 \\
Marital status & -.3386322 & .24684 & -1.37 & 0.170 \\
Farm size & -.086113 & .07275 & -1.18 & 0.237 \\
Availability of planting materials & -.0124518 & .03493 & -0.36 & 0.722 \\
\hline
\end{tabular}

Source: Own computation field survey data, 2019

Table 6 Constraints influencing farmers' decision to grow Bio-fortified Provitamin A Cassava

\begin{tabular}{|c|c|c|c|c|c|c|c|c|c|}
\hline \multirow[t]{2}{*}{ Constraints } & \multicolumn{2}{|c|}{$\begin{array}{l}\text { Agree } \\
\text { (3) }\end{array}$} & \multicolumn{2}{|c|}{$\begin{array}{c}\text { Disagree } \\
\text { (2) }\end{array}$} & \multicolumn{2}{|c|}{$\begin{array}{c}\text { Undecided } \\
\text { (1) }\end{array}$} & \multirow[t]{2}{*}{ Total } & \multirow[t]{2}{*}{ Mean } & \multirow[t]{2}{*}{ SD } \\
\hline & $\mathrm{F}$ & $\mathrm{S}$ & $\mathrm{F}$ & $\mathrm{S}$ & $\mathrm{F}$ & $S$ & & & \\
\hline $\begin{array}{l}\text { Poor access to } \\
\text { information sources }\end{array}$ & 68 & 204 & 16 & 32 & 6 & 6 & 242 & $2.69 *$ & 0.593 \\
\hline $\begin{array}{l}\text { Poor access to biofortified } \\
\text { provitamin A Stem }\end{array}$ & 56 & 168 & 25 & 50 & 9 & 9 & 227 & $2.52 *$ & 0.674 \\
\hline High moisture content & 50 & 150 & 26 & 52 & 14 & 14 & 216 & $2.40 *$ & 0.747 \\
\hline $\begin{array}{l}\text { Non acceptance of } \\
\text { products }\end{array}$ & 28 & 84 & 40 & 80 & 22 & 22 & 186 & $2.07 *$ & 0.747 \\
\hline High Fibre content & 26 & 78 & 45 & 90 & 19 & 19 & 187 & $2.08 *$ & 0.707 \\
\hline Poor access to market & 21 & 63 & 53 & 106 & 16 & 16 & 185 & $2.06^{*}$ & 0.642 \\
\hline Prone to pest attack & 12 & 36 & 55 & 110 & 23 & 23 & 169 & 1.877 & 0.615 \\
\hline
\end{tabular}

Source: Own computation from field survey data, 2019; SD = Standard Deviation

*Discriminating index $=2.0$

Journal of the Faculty of Agriculture and Veterinary Medicine, Imo State University Owerri website: www ajol.info/index.php/jafs

Open Access article distributed under the terms of the Creative Commons License CC BY-NC 